\title{
Comparative study of the two-period of epidemiological analysis of risk factors for breast cancer in Indonesia. Does it change?
}

Muchlis Ramli*, Setyawati Budiningsih ${ }^{\dagger}$, Yoshiyuki Ohno , Didid Tjindarbumi*, Goi Sakamoto ${ }^{\S}$ Santoso Cornain\#, Joedo Prihartono ${ }^{\dagger}$, Idral Darwis*, Sadao Suzuki*, Gunawan Tjahjadi", Kenji Wakai , Drupadi S Dillonף, Esti Soetrisno", Endang Sri Roostini\#, Susumu Watanabe ${ }^{\infty}$

\begin{abstract}
Abstrak
Penelitian kasus kontrol kanker payudara dalam aspek epidemiologi, khususnya tentang faktor risiko telah dua kali dilakukan di Indonesia. Pertama kali dalam tahun 1980-1981 (selama satu tahun) di Fakultas Kedokteran Universitas Indonesia, dalam hal ini kerjasama antara Bagian Kedokteran Komunitas dan Bagian Bedah yang melibatkan 90 kasus kanker payudara, 90 kasus kontrol. Penelitian kedua, yaitu yang terakhir ini, dengan inisiator dari International Collaborative Study on Breast Cancer antara Tim Universitas Indonesia dengan Tim Jepang (Nagoya University dan Tokyo Cancer Institute) yang melibatkan lebih banyak kasus, yaitu 300 kasus kanker payudara dan 600 kontrol. Study banding yang dilakukan antara kedua penelitian ini memperoleh hasil sebagai berikut; diperkirakan belum ada perubahan pergeseran distribusi umur penderita kanker payudara dengan peak of age yaitu pada usia 40-49 tahun. Juga belum tampak perubahan yang berarti dalam distribusi stadium kanker payudara, walaupun sejak awal tahun 1970-an sudah dilakukan program deteksi dini yang dipelopori oleh YKI (Yayasan Kanker Indonesia). Perbedaan IO tahun belum memperlihatkan pula perubahan distribusi pendidikan dari penderita kanker payudara. Tentang faktor risiko ditemukan bahwa pada studi pertama, radiasi dan riwayat trauma merupakan faktor risiko yang signifikan secara statistik, sementara obesity (kegemukan), status perkawinan, kehamilan dan laktasi merupakan faktor risiko yang tidak signifikan secara statistik. Pada studi kedua, ditemukan hasil bahwa perkawinan dan radiasi mempunyai efek proteksi terhadap terjadinya kanker payudara. Sebaliknya, perceraian, menjanda, kehamilan, laktasi dan trauma merupakan faktor yang dapat meningkatkan risiko terjadinya kanker payudara. Diperlukan penelitian lebih lanjut untuk mendapatkan hasil yang lebih bermakna.
\end{abstract}

\begin{abstract}
A case control study of epidemiological aspect of breast cancer especially concerning the risk factors and lifestyles in breast cancer patients had been carried out twice in Indonesia. Firstly in 1980-1981 (one year), performed by the University of Indonesia, Faculty of Medicine, Department of Community Medicine and Department of Surgery and 90 cases of breast cancer were compared to 90 controls. In the second study, performed under the International Collaborative Study on Breast Cancer between Indonesia and Japan (University of Indonesia from Indonesia and Nagoya University and Cancer Institute Tokyo from Japan), 300 cases of breast cancer were compared to 600 matched controls. In comparative analysis between the two studies, the following findings were obtained. It was estimated that there was no change of age distribution of breast cancer, which peaked at the age group of 40-49. There was no significant change of the stage distribution of breast cancer, although early detection program pioneered by Indonesia Cancer Foundation had been carried out since twenty years ago. Ten years difference was seen between the first study and the second study, while the distribution of cases according to education did not change significantly. The result of risk factor analysis showed that only irradiation and history of trauma increased the risk of breast cancer significantly in the first study, while obese, marital status, illiterate, pregnancy and lactation did not cause significant difference. In the second study, it was found that marriage and irradiation had protective effect in the development of breast cancer; while separated, widowed status, illiterate, pregnancy, lactation and trauma were found as significant risk factors in breast cancer development.
\end{abstract}

Keywords: Breast cancer, case-control study, epidemiological analysis

\footnotetext{
* Department of Surgery, Faculty of Medicine, University of Indonesia, Jakarta 10430, Indonesia

+ Department of Community Medicine, Faculty of Medicine, University of Indonesia, Jakarta 10320, Indonesia

- Department of Preventive Medicine, School of Medicine, Nagoya University, Nagoya 466, Japan

Department of Pathology, Cancer Institute Hospital, Tokyo 170, Japan

\# Department of Pathology, Faculty of Medicine, University of Indonesia, Jakarta 10430, Indonesia

I Department of Nutrition, Faculty of Medicine, University of Indonesia, Jakarta 10430, Indonesia

${ }^{\infty}$ Department of Surgery, Cancer Institute Hospital, Tokyo 170, Japan
} 


\section{INTRODUCTION}

Breast cancer is the second among ten most frequent cancers in Indonesia.' In America, it was reported that breast cancer will strike one of every ten females, accounting for $32 \%$ of all cancer in female with morality rate has remained unchanged for 50 years, i.e. 28 per 100.000 . Our data also showed that breast cancer has been slowly increasing in incidence and prevalence..$^{2-4}$ There is at least a fivefold variation in the incidence of breast cancer reported among different countries, although this difference appears to be narrowing. 5,6

In Hawaii, the incidence rate of breast cancer per 100.000 in different racial groups were as follows: white 80.3; Hawaiian 66.2; Chinese 54.2; Japanese 44.2; and Filipino 21.5. Buell reported in 1977 that Japanese migrants in the United States were exhibiting the breast cancer incidence rate similar to their adopted country rather than their own country of origin. The age specific incidence rate for Japanese women in Okayama, in those younger than 50 years was about a one fifth that of white woman in San Francisco, where as Japanese American women showed that the rate approaching those in white. 6,7

Breast cancer could also be found on the male breast, but the rate was very low. The ratio of incidence between female and male breast cancer was approximately 100 to 1 in almost all area. Marital status could also influence the development of breast cancer and the data showed that breast cancer was found more frequent on the unmarried women while it was also more frequent among women who marriage in late age as compared to women marriage in young age. It has been also reported that body constitution might influence breast cancer incidence. Breast cancer occurred more frequently in fatty women than thin ones. Trauma has been considered as risk factor, since $9 \%$ of breast cancer patients had breast trauma experience and only $2 \%$ in the control group. 8,9

Earlier studies reported that genetic trait was a significant risk factor. Female relatives of woman with breast cancer had about three times increased risk. The degree of risk depends on the number and closeness of the affected relatives.9,10 Patients who have had a biopsy for a benign lesion of breast cancer had a tripled risk of breast cancer, while patients with gross cystic disease had four times increased risk. The parity also influence breast cancer incidence, nulliparous women have three times increased risk for developing breast cancer.
There are many other factors, as risk for breast cancer had been reported; for example menstrual activity, menopause and ionizing radiation. Prolonged menstrual activity increases the risk of breast cancer. Artificial menopause before the age 37 resulted in a three-time decreased of risk. However, recommendation of such castration would certainly not be well accepted. ${ }^{8}$ Hypertension, diabetic and obese patient also has an increased risk of breast cancer approximately three-time. Besides, some other factors tend to influence the development of breast cancer, such as family planning program, infertility, limited lactation period, early menarche, religion and socio-economic status.

Indonesia archipelago consists of thousands islands with many ethnic groups with different culture and life style. This raises the following question, whether such heterogenerity in Indonesia cause some difference in risk factor of breast cancer in Indonesia as compared to other countries?

Two epidemiological studies on breast cancer in Indonesia had been performed, with approximately ten years interval, between the first study and the second one. The first study was carried out in 1981, with the title: "Epidemiological study of breast cancer in Indonesia. A case control study." conducted by the University of Indonesia (Department of Surgery and Department of Community Medicine). 8 The second was "Epidemiological study on breast cancer in Indonesia. A case control study." conducted by the International Collaborative Study on Breast Cancer between Japan and Indonesia.9-11 The results of the two studies will be compared in this paper. Various risk factors studied will be analyzed accordingly and evaluated for some changes, if any, during the ten years interval. Ten years interval means two periods of 5 years the Indonesia Government Program in Development, with following changes: improvements of socioeconomic condition/status, educational level, field of occupation and development of culture and life style.

\section{MATERIALS AND METHODS}

Comparison of two epidemiological studies of breast cancer were performed on two studies carried out independently with ten years interval.

The first study (FS) was performed by the Faculty of Medicine, University of Indonesia, Jakarta, from 1980-1981. The female breast cancer cases were collected from three hospitals and they were compared to 90 controls without breast tumors. The second 
study (SS) was performed by the Faculty of Medicine, University of Indonesia, Jakarta in collaboration with Nagoya City University and Nagoya University, Schools of Medicine, Nagoya, Japan, from 1988 to 1991. Ninety female breast cancer cases were collected from Dr. Cipto Mangunkusumo National General Hospital, Jakarta. Controls were females without lump in the breast and were matched with cases for age (ca 3 yrs) and socio-economic status.

The comparison of the first study and the second study were made in relation to the following aspects: type of studies were similar, namely case-control study (CCS), collected by using standard questionnaires; various aspects studied in both studies were similar, namely different risk factors and life styles: demographic characteristic, reproductive status, exposures to external factors and other factors.

\section{RESULTS}

\section{Clinicopathological data of breast cancer (second study)}

Clinicopathological data of breast cancer were not available from the first study. The data from the second study, namely the age distribution of cases as compared to controls are given in Table 1. The mean age and SD of the cases and controls were comparable, namely 46.9 yrs \pm 12.0 versus $46.9 \pm 12.0$ respectively.

The distribution according to clinical staging is given in Table 2. The majority of cases were in late stages, namely stages $3 \mathrm{~A}$ and above.
Table 2. Percentage of cases according to the stage of cancer

\begin{tabular}{lrr}
\hline Stage & N & $\%$ \\
\hline 1 & 6 & 2.00 \\
2 & 48 & 16.00 \\
3A & 69 & 23.00 \\
3B & 120 & 40.00 \\
4 & 67 & 19.00 \\
\hline Total & 300 & 100.00 \\
\hline
\end{tabular}

\section{Comparison of risk factors between the first study and the second study}

The data on various risk factors obtained during the first study and the second study are given in Table 3 . They were grouped in demographic data, reproductive status, exposures to external factors and miscellaneous. The demographic characteristics analyzed in the first study were educational level, working status and socio-economic status. Non-educated status increased the risk significantly. In the second study educated status at senior high school decreased the risk significantly, with $\mathrm{RR}=0.41$ and $95 \% \mathrm{CI}$ of $0.21-0.88$. Working status analysis showed that no-labor status increased the risk significantly, with $\mathrm{RR}=$ 2.5 and $95 \%$ CI of 1.22-4.17. Low socio-economic status also showed increased risk, with $\mathrm{RR}=2.04$ and $95 \% \mathrm{CI}$ of $1.03-4.06$.

Concerning the reproductive status, the following results were obtained. In the first study, the age of menarche did not show significant result. However, the second study showed that late menarche (above $15 \mathrm{yrs}$ ) increased the risk significantly, with $\mathrm{RR}=$ 2.36 and $95 \% \mathrm{CI}$ of $1.60-3.50$. There was no differ-

Table 1. Distribution of age among cases and controls

\begin{tabular}{|c|c|c|c|c|c|c|}
\hline \multirow[t]{2}{*}{ Age (years) } & \multicolumn{2}{|c|}{ Cases } & \multirow[t]{2}{*}{ Mean $\pm \mathrm{SD}$} & \multicolumn{2}{|c|}{ Controls } & \multirow[t]{2}{*}{ Mean \pm SD } \\
\hline & $\mathrm{n}$ & $\%$ & & $\mathrm{n}$ & $\%$ & \\
\hline$<35$ & 51 & 17 & $46.9 \pm 12.1$ & 104 & 17.3 & $46.9 \pm 12.0$ \\
\hline $35-39$ & 34 & 11.3 & & 93 & 15.5 & \\
\hline $40-44$ & 51 & 17 & & 71 & 11.8 & \\
\hline $45-49$ & 42 & 14 & & 84 & 14 & \\
\hline $50-54$ & 29 & 9.7 & & 64 & 10.7 & \\
\hline $55-59$ & 26 & 8.7 & & 61 & 10.2 & \\
\hline $60-64$ & 46 & 25.3 & & 73 & 12.2 & \\
\hline $65-69$ & 12 & 4 & & 35 & 5.8 & \\
\hline$>70$ & 9 & 3 & & 15 & 2.5 & \\
\hline Total & 300 & & & 600 & & \\
\hline
\end{tabular}


ence of the risk due to the age of marriage. In the first study, marital status did not influence the risk. However, separated women showed decreased risk in the second study, with RR $=0.37$ and $95 \% \mathrm{CI}$ of 0.21 0.65 . Pregnancy at young age (less than $19 \mathrm{yrs}$ ) of age decreased the risk as shown in the first study. Decreased risk was also seen in the first study in women who have never got pregnancy as compared to the ones with pregnancy, with $\mathrm{RR}=0.16$ and $95 \% \mathrm{CI}$ of $0.16-0.64$. The data in the second study showed that limited number (1-2) of pregnancy increased the risk, with $\mathrm{RR}=1.51$ and $95 \% \mathrm{CI}$ of $1.02-2.23$. Increased risk was seen in the first study in relation to the increasing number of live births, with significant effect at $1-3$ live births with $\mathrm{RR}=12.0$ and $95 \% \mathrm{CI}$ of 4.87 - 29.4. On the contrary, the second study resulted in the decreasing risks with the increasing number of live births. Significant effect was seen at 3-5 live births, with RR $=0.32$ and $95 \%$ CI of $0.17-0.61$. Increased risk was shown in the first study in relation to women lactating children as compared to non-lactating ones. In the second study, the effect of lactation was evaluated in respect to length of breast feeding. The results showed that increased risk was related to very short lactation period, with $\mathrm{RR}=5.44$ and $95 \%$ CI of $1.88-15.75$.

Menopausal status increased significantly the risk in the first study as evaluated against the time either at less than 45 yrs of age with RR $=29.2$ and $95 \% \mathrm{CI}$ of $3.74-2.27$, or at $45-55 \mathrm{yrs}$ of age with $\mathrm{RR}=7.55$ and $95 \% \mathrm{CI}$ of $3.06-18.51$. The effect was confirmed in the second study as evaluated against the process of menopause, either naturally with $\mathrm{RR}=1.38$ and $95 \% \mathrm{CI}$ of $1.04-1.84$ or induced one with $\mathrm{RR}=5.96$ and $95 \% \mathrm{CI}$ of $2.78-12.79$.
Exposures to external factors including ovary surgery, contraception, exposure to X-ray and breast trauma were also analyzed. In the first study, ovary surgery was found to increase the risk, with $\mathrm{RR}=1.1$. and $95 \% \mathrm{CI}$ of $1.39-88.8$. The use of contraception did not show significant effect in the first study, but it increased the risk significantly in the second study, with $\mathrm{RR}=4.63$ and $95 \% \mathrm{CI}$ of $1.67-12.84$. Increased risk was found due to exposure to X-ray in the first study, with $R R=6.1$ and $95 \%$ CI of $3.32-28.5$. During the second study, the X-ray exposure was distinguished between indirect and direct exposure. Somewhat different results were obtained, showing no influence on decreased risk by indirect exposure, with $\mathrm{RR}=0.08$ and $95 \% \mathrm{CI}$ of $0.02-0.4$. The discrepancy might be due to small samples. Breast trauma caused increased risk in the first study with $\mathrm{RR}=3.62$ and $95 \%$ CI of 0.96 - 13.6, which significance was marginal, and it was confirmed significantly in the second study with RR $=1.88$ and $95 \% \mathrm{CI}$ of $1.09-3.25$.

In addition, several factor abnormalities were analyzed, i.e. history of breast furuncle, obesity, diabetes mellitus and the breast size. Women who had breast furuncle increased the risk significantly, with $\mathrm{RR}=$ 6.8 and $95 \% \mathrm{CI}$ of $1.47-31.2$. Obesity tended to show increased risk in the first study, with $\mathrm{RR}=1.92$ and $95 \% \mathrm{CI}$ of $0.90-4.09$, which was similarly shown in the second study, with $\mathrm{RR}=1.32$ and $95 \%$ CI of 0.87 - 1.97. However, the data showed significantly decreased risk in the women with overweight, with $\mathrm{RR}=0.32$ and $95 \% \mathrm{CI}$ of $0.22-0.45$.

The data from the first study indicated that diabetes mellitus caused increased risk, with $\mathrm{RR}=8.7$ and $95 \%$ CI of $1.06-70.9$. Size of breast was not a significant risk factor.

Table 3. Risk factor analysis of breast cancer in the first and second study

\begin{tabular}{llllll}
\hline First study & & & Second study & & \\
Factor & Case Control & RR $(95 \% \mathrm{CI})$ & Factor & Case Control & RR (95\% CI) \\
\hline
\end{tabular}

\section{Demographic characteristic}

Education

School educated

Non-educated

$\begin{array}{rrrl}65 & 85 & 1.00 & \text { (Reference) } \\ 25 & 5 & 6.54 & (2.37-18.0)^{*}\end{array}$

\section{Working status}

$\begin{array}{lllll}\text { Labor } & 26 & 43 & 1.00 \text { (Reference) } \\ \text { No labor } & 64 & 47 & 2.5 & (1.22-4.17)^{*}\end{array}$

$\begin{array}{lrrrl}\text { Education } & & & & \\ \text { University } & 15 & 17 & 1.00 \text { (Reference) } \\ \text { Senior high school } & 53 & 146 & 0.41 & (0.21-0.88)^{*} \\ \text { Junior high school } & 46 & 93 & 0.56 & (0.26-1.22) \\ \text { Elementary school } & 108 & 195 & 0.63 & (0.30-1.30) \\ \text { Illiterate } & 78 & 149 & 0.59 & (0.28-1.25)\end{array}$


Socio-economic status

Medium-high

Low

\section{Reproductive status}

\section{Age at menarche}

11-15 yrs

$<11$ and $>15$ yrs

\section{2}

15

44

1.00 (Reference)

$0.70(0.31-1.62)$

Age at marriage

Above $19 \mathrm{yrs}$

Under 19 yrs

Marital status

Married

Separated

Widow

Unmarried

$42 \quad 32 \quad 1.00$ (Reference)

$\begin{array}{llll}35 & 14 & 1.9 & (0.88-4.12)\end{array}$

$68 \quad 52 \quad 1.00$ (Reference)

$\begin{array}{llll}1 & 0 & 1.31 & (0.08-21.4)\end{array}$

$14 \quad 3 \quad 0.28 \quad(0.08-1.03)$

$\begin{array}{llll}7 & 4 & 1.34 & (0.37-4.82)\end{array}$ $\begin{array}{llll}80 & 73 & 1.00 & \text { (Reference) } \\ 10 & 17 & 2.04 & (1.03-4.06)^{*}\end{array}$

Test for trend: 2.416
Age at menarche

$<15$ yrs

$>15$ yrs
71

175
$92 \quad 1.00$ (Reference)

$952.36(1.60-3.50)^{*}$

$\begin{array}{lrrrl}\text { Marital status } & & & & \\ \text { Married } & 197 & 331 & 1.00 \text { (Reference) } \\ \text { Separated } & 16 & 72 & 0.37(0.21-0.65)^{*} \\ \text { Widow } & 64 & 157 & 0.68(0.49-0.96)^{*} \\ \text { Unmarried } & 23 & 39 & 0.99(0.57-1.75)\end{array}$

Test for trend: 3.148

$\begin{array}{llll}\begin{array}{l}\text { Age at } 1^{\text {st }} \text { pregnancy } \\ 19-35 \text { yrs }\end{array} & 52 & 23 & 1.00 \text { (Reference) } \\ \quad \text { Less than } 19 \text { yrs } & 38 & 67 & 0.25(0.13-0.47)^{*} \\ \quad \begin{array}{llll}\text { Pregnancy } \\ \text { Ever }\end{array} & 74 & 39 & 1.00 \text { (Reference) } \\ \quad \text { Never } & 16 & 51 & 0.16(0.08-0.33)^{*}\end{array}$

Number of live births

$\begin{array}{lllcl}\text { None } & 16 & 58 & 1.00 & \text { (Reference) } \\ 1-3 & 33 & 10 & 12.0 & (4.87-29.4)^{*} \\ >3 & 41 & 22 & 6.76 & (3.17-14.4)\end{array}$

Child lactation

Lactated

Non-lactated
$30 \quad 1.00$ (Reference)

$1960 \quad 0.13(0.02-0.26)^{*}$

Menopausal status

\begin{tabular}{ccccc} 
Not yet & 45 & 82 & 1.00 & (Reference) \\
At less than 45 yrs & 16 & 1 & 29.2 & $(3.74-2.27)^{*}$ \\
At $45-55$ yrs & 29 & 7 & 7.55 & $(3.06-18.6)^{*}$ \\
\multicolumn{4}{r}{ Test for trend: } & $29.588^{* * * *}$
\end{tabular}

\section{Exposures to external factors}

\section{Ovary surgery}

No
Yes

$$
80
$$$$
10
$$

$87 \quad 1.00$ (Reference)

Contraception

No

Yes
64

26
$68 \quad 1.00$ (Reference)

$22 \quad 1.3 \quad(0.65-2.44)$

\section{Pregnancy}

$\begin{array}{lrrrl}>5 & 109 & 226 & 1.00 & \text { (Reference) } \\ \text { None } & 40 & 81 & 1.02 & (0.66-1.59) \\ 1-2 & 67 & 92 & 1.51 & (1.02-2.23)^{*} \\ 3-4 & 79 & 197 & 0.83 & (0.59-1.18) \\ & \text { Test for trend: } 0.226 & & & \end{array}$

Number of live births

$\begin{array}{lrrrl}\text { None } & 25 & 22 & 1.00 & \text { (Reference) } \\ 1-2 & 44 & 35 & 1.11 & (0.54-2.28) \\ 3-5 & 55 & 150 & 0.32 & (0.17-0.61)^{*} \\ >6 & 36 & 60 & 0.52 & (0.25-1.03) \\ & \text { Test for trend: } 10.36]^{* *} & & & \end{array}$

Child lactation

$\begin{array}{lrrll}\text { Long } & 216 & 472 & 1.00 & \text { (Reference) } \\ \text { Average } & 15 & 18 & 1.82 & (0.91-3.65) \\ \text { Short } & 7 & 10 & 5.33 & (0.58-4.04) \\ \text { Very short } & 9 & 3 & 5.44 & (1.88-15.75)^{*} \\ \text { Never } & 49 & 94 & 1.14 & (0.78-1.67) \\ & \text { Test for trend: } & 2.111 & & \end{array}$

Menopausal status

$\begin{array}{lrrrl}\text { Not yet } & 135 & 329 & 1.00 & \text { (Reference) } \\ \text { Naturally } & 145 & 263 & 1.38 & (1.04-1.84)^{*} \\ \text { Induced } & 19 & 8 & 5.96 & (2.78-12.79)^{*}\end{array}$




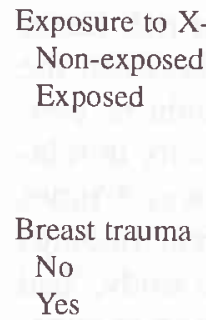

\section{Miscellaneous}

$\begin{array}{lrrrl}\text { No } & 80 & 87 & 1.00 & \text { (Reference) } \\ \text { Yes } & 10 & 3 & 3.62 & (0.963-13.6) \\ \text { IV. Miscellaneous } & & & & \\ \text { History of breast furuncle } & & & & \\ \quad \text { No } & 78 & 88 & 1.00 \text { (Reference) } \\ \quad \text { Yes } & 12 & 2 & 6.8 & (1.47-31.2)^{*} \\ \text { Obesity } & & & & \\ \quad \text { Non obese } & 68 & 77 & 1.00 \text { (Reference) } \\ \quad \text { Obese } & 22 & 13 & 1.92 \text { (0.90-4.09) }\end{array}$

$\begin{array}{rrrl}79 & 88 & 1.00 & \text { (Reference) } \\ 11 & 2 & 6.13 & (1.32-28.5)^{*}\end{array}$

$\begin{array}{lrrrl}\begin{array}{l}\text { Diabetes mellitus } \\ \text { Non-diabetic }\end{array} & 82 & 89 & 1.00 \text { (Reference) } \\ \begin{array}{l}\text { Diabetic } \\ \text { Size of breast }\end{array} & 8 & 1 & 8.7 & (1.06-70.9)^{*} \\ \text { Average } & & & & \\ \text { Smali } & 47 & 25 & 1.00 \text { (Reference) } \\ \text { Big } & 25 & 10 & 1.33 & (0.55-3.20) \\ & 18 & 16 & 0.60 & (0.26-1.37)\end{array}$

$\begin{array}{lrrrr}\begin{array}{l}\text { Exposure to X-ray } \\ \text { Non-exposed }\end{array} & 46 & 91 & 1.00 \text { (Reference) } \\ \text { Indirectly exposed } & 1 & 25 & 0.08 & (0.02-0.4)^{*} \\ \text { Directly exposed } & 253 & 484 & 1.03 & (0.79-1.52) \\ \quad \text { Test for trend: } & 0.465 & & & \end{array}$

$\begin{array}{lrrrl}\text { Breast trauma } & & & & \\ \text { No } & 271 & 549 & 1.00 \text { (Reference) } \\ \text { Yes } & 26 & 28 & 1.88 \text { (1.09-3.25)* }\end{array}$

\section{Obesity \\ $\begin{array}{lllll}\text { Normal weight } & 92 & 162 & 1.00 & \text { (Reference) }\end{array}$ \\ Over weight $\quad 109 \quad 319 \quad 0.32(0.22-0.45)^{*}$ \\ $\begin{array}{lrrrr}\text { Obese } & 67 & 90 & 1.31 & (0.87-1.97)\end{array}$}

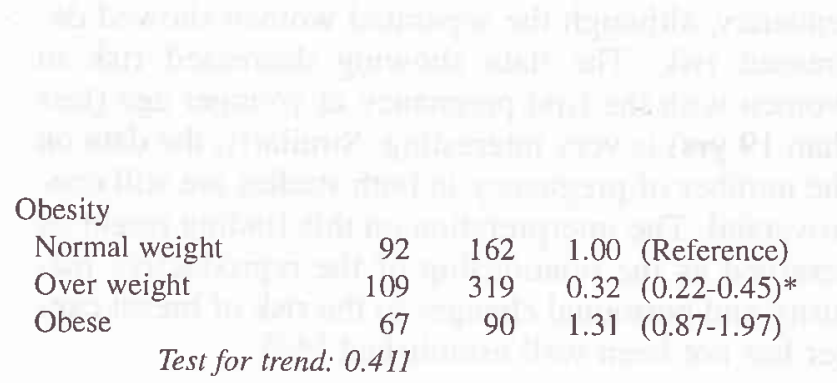

* Significant

** Test for trend: Significant at $p<0.0025$

*** Test for trend: Significant at $p<0.001$

\section{DISCUSSION}

Since the age distribution of breast cancer patients in the first study was not evaluated, the data of the second study was compared to the data in two publications beyond the year 1981. Simanjuntak reported in 1978 that age distribution of 147 cases of breast cancer peaked at 41 - 50 years old (34\%), 31 - 40 years old $(27.9 \%)$ and $51-60$ years old $(21 \%)$. Tjindarbumi in 1984 reported that from 382 cases of breast cancer, peak of age was on the age of $41-50(33.4 \%)$ followed by the age of $31-40(23.2 \%)$ and $51-60$ $(28.8 \%)$. In the second study peak of age was also on $40-49$, which was about $31 \%$, then age of $50-59$ $(23.7 \%)$ and age below $39(28.3 \%)$. So, within ten years there was no change of age distribution especially about peak of age; but it is seen that there is shifting of cases to the elder age. Maybe this shifting is parallel to increase of life expectancy of the Indonesian people during the last ten years.

The data of distribution of clinical staging, was also not evaluated in the first study; but Tjindarbumi reported that among 382 cases of breast cancer in 1980-
1983 at Dr.Cipto Mangunkusumo Hospital, they could be classified as follows: stage I: $3.9 \%$, II: $17 \%$, III: $65.6 \%$ and IV: $13.4 \%$. If this data compared to the data in the second study, it showed that there was no change of disrtibution according to clinical staging distribution within ten years.

The results of risk factor analysis performed in both studies were very interesting. Significant findings were obtained in demographic analysis. Non-educated status showed increased risk in the first study, while high level of education (senior high school) showed decreased risk in the second study. Taken together, the data indicated that education could contribute as protective effect probably due to certain degree of knowledge on health care in general and cancer case in particular.

The effect of non-labor and low-socio-economical level to increase the risk might be consistent with similar of low or lack of education. A rule, certain demographic characteristics interact each other in resulting a given effect or risk. 
It is of different that the unclear effect of the age of menarche in the first study was clarified by the outcome of the second study, that women with late menarche (over 15 yrs of age) showed increased risk significantly. However, this particular risk factor still needs to be analyzed since controversial results were reported.3,4,13,15 Concerning the effect of marital status, the findings did not show certain pattern or tendency, although the separated women showed decreased risk. The data showing decreased risk in women with the first pregnancy at younger age (less than $19 \mathrm{yrs}$ ) is very interesting. Similarly, the data on the number of pregnancy in both studies are still controversial. The interpretation on this finding might be reserved as the relationship of the reproductive maturity and hormonal changes to the risk of breast cancer has not been well established.3,4,16

However, from the data of number of live births and number or the length of chilren lactation, it appeared that lactating children could be a protective factor. Such finding has been also reported elsewhere. The findings on the effect of menopause to increase the risk of breast cancer could be established by both studies.

Further analysis has been performed during the second study by separate analysis of risk factors among pre-menopausal and post-menopausal women respectively.10,11 Exposure to certain external factors has been generally expected to cause increased risk in breast cancer. Increased risk related to ovary surgery appeared to be on the contrary to the well-known hormonal deprivation effect to inhibit the growth of breast cancer. Such inconsistent finding might be due to small samples and should be reserved.

Our present finding on the effect of contraception to increase the risk should be taken into account although it was based on small number of samples, since the effect of this risk factor is still controversial.

Unfortunately, the effect on exposure to X-ray from both studies could not clarify the general assumption about the risk and relation to ionizing radiation. Looking on the data of both studies, the effect of breast trauma to increase the risk could be confirmed. The increased risks, in relation to history of breast furuncle and diabetes mellitus, and the marginal significant effect of obesity are noteworthy.

Genetic trait as risk factor was not studied in the first study, so it could not be compared. Where in the sec- ond study, genetic trait was an important risk factor with $R R=2.85$. Several discrepancies between the findings in the first and second study, might be conceivable to bias influenced by heterogenecity in relatively small samples. The power of SS was 3 times higher than the FS, therefore, the different findings need clarifying. In addition, in the second study, 'bad fatty diet' (consuming fatty meat, fatty food or coconut milk daily) was significantly found as risk factor for breast cancer $(\mathrm{RR}=2.63 ; 95 \% \mathrm{CI}=1.45-4.79) .{ }^{9-}$ 12 The finding was appreciable since it was elucidated in the population with relatively low fat dietary habit.

Some other factors were also studies, such as geographical origin (urban, rural), fatty diet and smoking. The result showed that smoking was not found as a risk factor for breast cancer, but the other two factors were found as risk factors.

The trend of increasing incidence rate of breast cancer has been observed during the last decade, with anticipated increasing problems. ${ }^{13-17}$ Therefore, the remaining problems as revealed in the present comparative study needs clarifying.

The problems include the fact of the majority of cases were in late stage due to delayed presentation of the disease which require early detection and preventive measures.3,4,18 In Addition, for improving therapy, many studies have been reported on the relationship of the tumor biological markers with response therapy. ${ }^{19-22}$

\section{CONCLUSION}

In comparative analysis between the both studies were found that; it was estimated that there was no change of age distribution of breast cancer, where peak of age still in $40-49$. Also estimated that there was no significant change of stage distribution of breast cancer, the program of early detection pioneered by the Indonesian Cancer Foundation had been applied since 20 years ago. Ten years different between the first and the second study, but distribution of cases concerning of education did not significant change yet. The results of risk factors analysis for breast cancer revealed that obese and illiterate status did not show significant risk in both studies. During the first study, different marriage status did not show significant risk, while separated and widowed status significantly reduced the risk, with OR \& CI of $0.5 \& 0.02-6.98$ and $0.64 \& 0.26-1.58$ respectively. 
The risk of different number of pregnancy was not significant in the first study, while minimal (1-2) pregnancy increased the risk in the second study (OR $=1.51 \& C I=1.02-2.23$ ). Similarly, the duration of lactating children was not significant in the first study, while very short duration of lactation increased the risk in the second study $(\mathrm{OR}=5.44 \& \mathrm{CI}=1.88$ - 15.75). The first study showed that history of X-ray increased the risk $(\mathrm{OR}=11 \& \mathrm{CI}=1.48-2.28)$. However, the second study showed that indirect $\mathrm{X}$ ray reduced the risk $(\mathrm{OR}=0.08 \& \mathrm{CI} 0.02-0.4)$.

Both studies showed that breast trauma increased the risk $(\mathrm{OR}=5 ; \mathrm{CI}=1.04-3.3$ and $\mathrm{OR}=1.88 ; \mathrm{CI}=$ $1.09-3.25$ respectively).

\section{Acknowledgments}

The authors are grateful to the nurses, Ms. Emi and Ms. Ros and for public health nurses, Ms. July and Ms. Erlaini for excellent care and collection of data of breast cancer cases and controls. We are also indebted to the laboratory technician for excellent work on the surgicopathological specimens.

This work was supported by the Ministry of Education, Science, Sports and Culture of Japanese Government, Grants No. 01042007, 04042013 and 06042006; and was partly supported by the Indonesian Cancer Foundation. This collaborative study was a part of Special Cancer Research Project in Monbusho Intemational Scientific Research Program, with the approval of the Dean, Faculty of Medicine University of Indonesia, No. 4383/PT02.H4.FK/E/ 88.

\section{REFERENCES}

1. Cornain S, Mangunkusumo R, Nasar IM, Prihartono J. Ten most frequent cancers in Indonesia: Pathology based cancer registry data of 1988-1992. In: Cancer Registry in Indonesia. National Cancer Registry Center, Jakarta Coordinating Board, 1997.

2. Petrakis NL, Ernester VL, King M. Breast, In: Schattenfield D, Franmeni JF, editors. Cancer epidemiology and prevention. WB Saunders, Co, Philadelphia 1922; p.858-70.

3. Donn AS, Muir CS. Breast cancer: Epidemiology and risk factors. In: Khogali M, Onar YT, Gjorgov A, Ismail AS, editors. Cancer Prevention in Developing Countries. Pergamon Press, Oxford, 1986: p. 155-55.

4. Keisey JL, Hom-Ross PL. Breast Cancer: Magnitude of the Problem and Descriptive Epidemiology. Epidemiologic Review 1993; 15: 7-16.

5. WHO, IARC. Cancer incidence in five continents. IARC Publ No. 15, Vol. III Lyon, 1976.
6. Parkin DM, Laura E, Muir CS. Estimates of the worldwide frequency of sixteen major cancers in 1980. Int J Cancer 1988; 41: 184-97.

7. Buell P. Changing incidence of breast cancer in Japanese American woman. J Nat Cancer Institute, 1973; 51: 1479-83.

8. Lapau B, Sukrima B, Ramli M, Sumirat, Sudarmo S. Epidemiological study on breast cancer in Jakarta. Preliminary Report, University of Indonesia, Faculty of Medicine, Jakarta1982.

9. Budiningsih S, Ohno Y, Prihartono J, Ramli M, Cornain S, et al. Epidemiological analysis of risk factors for breast cancer in Indonesian females. Med J Indones 1995; 4: 163-8.

10. Suzuki S, Prihartono J, Ohno Y, Budiningsih S, Wakai K, Cornain $S$, et al. Epidemiologic risk factors for breast cancer related to menopausal status in Indonesia. Med J Indones 1995; 4: 169-76.

11. Cornain S, Ohno Y, Prihartono J, Sakamoto G, Tjahjadi G, Tjindarbumi D, et al. Similar and dissimilar findings in Japan-Indonesia case-control study on breast cancer: Two phases study. J Epidemiol 1996; 6: S175-S 180.

12. Cornain S, Ohno Y, Dillon DS, Prihartono J, Sakamoto G, Tjahjadi G, et al. Nutritional risk factor analysis in Japan-Indonesia joint study on breast cancer. Jpn J Cancer Clin 1997; 43: 413-9.

13. Wakai K, Suzuki S, Ohno Y, Kawamura T, Tamakoshi A, Aoki R. Epidemiology of breast cancer in Japan. Int J Epidemiol 1995; 24: 285-91.

14. Parkin DM. The nature and sources of cancer data from developing countries. In: Khogali M, Omar YT, Gjorgov A, Ismail AS, editors. Cancer Prevention in Developing Countries. Proceedings of the $2^{\text {nd }}$ UICC Conference on Cancer Prevention, Kuwait, 1986. Oxford: Pergamon Press, 1986: 922

15. Stanley K, Stjernwärd J, Koroltchouck V. Women and cancer. Wld hlth status quart 1987; 40: 267-78.

16. Hulka BS, Liu ET, Liminger RA. Steroid hormones and risk of breast cancer. Cancer 1994; 74: 1111-24.

17. Sakamoto G, Sugano H. Pathology of breast cancer; Present and prospect in Japan. Breast Cancer Research and Treatment 1991;18: 581-3.

18. Cornain S. Strategic planning and research of cancer control in Indonesia (Eds): Cancer Epidemiology and Control in Asia-Pacific Region. Kobe University, Kobe 1999 (In press).

19. Lee HP. Gourley L, Duffy SW, Estéve J, Lee J, Day NE. Dietary effects on breast cancer risk in Singapore. The Lancet 1991; 337: 1197-200.

20. Lee AC, Rosero-Bixby L, Oberle MW, Grimaldo C, Whatley AS, Rovira EZ. A case-control study of breast cancer and hormonal contraception in Costa Rica. JNC 1987; 1247-54.

21. Block GE, Elword GE, Jensen EV, Polley TZ. The prediction of hormonal dependency of mammary cancer. Ann Surg 1975; 182: 342-51.

22. Mc Tiernan A, Thomas DB, Johnson LK, Roseman D. Risk factors for estrogen receptor rich and estrogen receptor-poor breast cancer. JNCI 1986; 77: 849-54. 